\title{
Evaluation of Some Antioxidants against Tomato Early Blight Disease
}

\author{
M.Z. El-Shennawy and A.M. Abd El-All \\ Agricultural Botany Department, Faculty of Agriculture, Menoufiya University, Egypt
}

\begin{abstract}
This work was carried out under greenhouse conditions during two successive seasons 2017 and 2018, at the Farm of Faculty of Agriculture, Menoufiya University, Shibin El-Kom to study the effect of three antioxidants i.e; salicylic acid, ascorbic acid and boric acid with two concentrations $(15$ and $30 \mathrm{mg} / \mathrm{l})$ on tomato early blight disease incidence, disease severity, some growth characters, water relations and chemical compositions of tomato plants. All treatments of antioxidants significantly reduced disease incidence and disease severity, in as much as, increased significantly plant height, leaf area fresh and dry weight, total water content (TWC), bound water, free water, relative water content (RWC) and transpiration rate. Also, application of antioxidants increase in chlorophyll A, chlorophyll B, carotenoids, total carbohydrates, total sugars, protein and prolien on tomato plants. Salicylic acid $(30 \mathrm{mg} / \mathrm{l})$ was the best treatment followed by the $(30 \mathrm{mgl} / \mathrm{l})$ of ascorbic acid While, boric acid $(15 \mathrm{mg} / \mathrm{l})$ recorded the least effect on disease severity, disease incidence, growth characters, water relations parameters and chemical compositions.
\end{abstract}

Key words: Tomato, Early blight, Salicylic acid, Ascorbic acid, Boric acid, Growth, Water relations, Chemical compositions.

\section{INTRODUCTION}

Tomato (Solanum lycopersicum L.) is one of the most important solanaceous crops in Egypt and in the world because of its high contents of vitamin $\mathrm{C}$ as well as many chemical compounds and elements. Early blight disease caused by Alternaria solani (Ellis \& Martin) Jones \& Grout is considered as one of the most widespread tomato disease which can affect the foliage, stems and fruits. The disease is responsible for significant economic losses sustained by tomato or potato producers each year (Esmail zadeh et al., 2008).

It is well known that using fungicides is considered as the shortest way to obtain efficient results for disease management. On the other hand, applications of fungicides have hazard effect on human and animal health. Therefore a more balanced, cost effective and eco-friendly approach must be implemented and adopted by farmers.

Antioxidants are resumed as alternative safety chemicals in this regard. According to Galal and Abdou (1996) some chemicals like antioxidants were reported as resistance inducers against plant disease.

Activating the natural defence mechanisms of the plant is one of the modern plant protection systems. Systemic acquired resistance (SAR) can be induced in various plants by chemical inducers.

Salicylic acid (SA) is an important signal molecule that plays a critical role in plant defence against pathogen invasion (Chaturredi and Shah, 2007). Application of salicylic acid has induced disease resistance on tomato plants against Alternaria leaf spot in glasshouse trials (Safari et al., 2013). According to Ismail, Amal (2015) compost extract and chemicals i.e., Bion, salicylic acid, oxalic acid, Rubigan $12 \%$ and Topas could be used for controlling early blight of potato plants under field conditions.

Ascorbic acid, as foliar spray, reduced significantly early and late blight diseases incidence on tomato under greenhouse condition (Abde ElKader et al., 2012). According to Awadalla, Omyma (2008) five antioxidants (citric acid, salicylic acid, benzoic acid, ascorbic acid and sodium citrate) markedly inhibited the mycelial growth of $A$. solani in vitro and increased tomato resistance to early blight in vivo. Hossain et al. (2015) reported that potato seed treatment with $3 \%$ boric acid resulted in good control of common scab incidence with higher tuber yield.

The main objective of the present research was to evaluate the efficacy of three antioxidants (salicylic acid, ascorbic acid and boric acid) as resistance inducers against early blight disease on tomato.

MATERIALS AND METHODS Isolation of Pathogen:

Samples of naturally infected leaves of tomato showing the early blight symptoms were collected from Vegetable Experiments Farm, Faculty of Agriculture, Shibin El-Kom, Egypt. Samples were subjected to isolation trials for the pathogenic fungus according to the method devised by Saad et al. (2014). The developed fungal colonies were purified on to Potato Dextrose Agar (PDA) medium by hyphal tip techniques. The purified cultures were identified depending on morphological and cultural characteristics (Ellis, 1971). Subcultures of the obtained isolate were kept on PDA slants and stored at $5^{\circ} \mathrm{C}$ until used. 
Effect of antioxidants on the mycelial growth of A. solani:

This experiment was carried out using the method of Mate et al. (2005). Each antioxidant was dissolved in sterile distilled water and added separately to autoclaved potato dextrose agar (PDA), $10 \mathrm{ml}$ of each concentration were added to $90 \mathrm{ml}$ of PDA in flasks, before solidification at two different concentrations (15 and $30 \mathrm{mg} / \mathrm{l})$ and using control without antioxidant. Four plates were used for each concentration ( $20 \mathrm{ml}$ of PDA media in each plate). Plates were rotated gently to ensure equal distribution of the added antioxidants. After solidification of media each plate was inoculated with $5 \mathrm{~mm}$ (diameter) disc from 8 days old culture of $A$. solani in the center. Inoculated plates were incubated at $25^{\circ} \mathrm{C}$ until mycelial growth of the pathogenic fungus covered the surface of the medium in control treatment. The percentage of the radial growth inhibition was calculated as the formula given by Jayasinghe and Wijesundera (1995).

Radial growth inhibition $(\%)=$

Growth in control - Growth in treatment

Growth in control
Greenhouse experiment:
Antioxidants (salicylic acid, ascorbic acid and boric acid) were tested for controlling early blight disease on tomato plants under greenhouse condition at the Experimental Farm, Faculty of Agriculture, Menoufiya University, Shibin El-Kom, Egypt. Two seedlings (cv. Super strain B) 30-daysold, were transplanted in plastic pot (25-cm-diam.) containing $3 \mathrm{~kg}$ of clay-sand mixed soil previously disinfested by $5 \%$ formalin. Two weeks later the plants were sprayed with antioxidant at two concentrations $(15$ and $30 \mathrm{mg} / \mathrm{l})(50 \mathrm{ml}$ for each pot). One week after antioxidant treatments, each of tomato plants was inoculated with $20 \mathrm{ml}$ of $A$. solani spore suspension containing $5 \times 10^{6} \mathrm{cfu} / \mathrm{ml}$ and kept under plastic bags for 48 hours to maintain high humidity (Abd El-Sayed, 2006). One week later, the plants received another spray with the tested antioxidants. Control plants were sprayed with the tested fungus only. Treatments were arranged in a completely randomized design. Five replicates were used for each treatment. Pots were watered as needed and fertilized with the recommended dose of $\mathrm{N}, \mathrm{P}, \mathrm{K}$ fertilizers. The disease incidence was recorded 40 days after transplanting, according to scale developed by Cohen et al. (1991) from $0-4$ based on the leaf area infected as follows:

$0=$ No. leaf lesions, $1=25 \%$ or less of leaf area infected, $2=26$ to $50 \%, 3=51$ to $75 \%$ and $4=76$ to $100 \%$ infected leaf area.

The disease severity (\%) was recorded according to Ismail, (2015) formula:
Disease severity $=\frac{\Sigma(\mathrm{N} \times \mathrm{V})}{\mathrm{G} \mathrm{N}} \times 100 \%$

$\mathrm{N}=$ Total number of the infected leaves,

$\mathrm{V}=$ Numerical grade,

$\mathrm{G}=$ Higher degree in the category. Also, Plant samples were taken to determine the following parameters:

1. Vegetative growth characters: Root length $(\mathrm{cm})$, plant height $(\mathrm{cm})$, leaf area per plant $\left(\mathrm{cm}^{2} /\right.$ plant). (Fladung and Ritter, 1991), fresh and dry weight of hole plant (g) (Plant materials were dried in an electric oven at $70^{\circ} \mathrm{C}$ for 72 hours).

2. Water relations: Total water content (TWC \%), free and bound water (Gosev, 1960 and Kreeb, 1990), relative water content (RWC \%) (Barrs and Weatherley, 1962), osmotic pressure (Gosev, 1960), transpiration rate (Kreeb, 1990).

3. Photosynthetic pigments: The photosynthetic pigments were extracted from fresh leaf sample (fourth upper leaf) by $85 \%$ acetone according to the method described by Wettestein's formula in A.O.A.C., 1995.

4. Chemical analysis: Total carbohydrates and total sugars were determined using the phenol sulfuric acid method as described by A.O.A.C. (1995). Proline concentration was measured according the method of Bates et al. (1973).

\section{Statistical analysis:}

All experiments were performed twice. The obtained data were subjected to analysis of variance (ANOVA) using Costat software, version 6.4 (2008). Duncan's multiple range test (DMRT) at $\mathrm{p}<$ 0.05 level was used for means separation (Gomez and Gomez (1984).

\section{RESULTS}

Data presented in Table (1) show that application of antioxidant; salicylic acid, ascorbic acid, boric acid at two different concentrations (15, $30 \mathrm{mg} / \mathrm{l}$ ) caused significant reduction on liner growth of Alternaria solani in vitro. The heights reduction was observed by salicylic acid $30 \mathrm{mg} / \mathrm{l}$ $(81.11 \%)$ followed by ascorbic acid $30 \mathrm{mg} / \mathrm{l}$ (76.66\%). On the other hand boric acid $15 \mathrm{mg} / 1$ gave the lowest effect on $A$. solani linear growth (51.11\%).

Presented data in Table (2 and 3) reveal that disease incidence and disease severity of early blight disease were reduced significantly in the two seasons 2017, 2018 when plants were sprayed with antioxidants compared with check treatment. Salicylic acid $30 \mathrm{mg} / \mathrm{l}$ had the greatest inhibitory effect on early blight disease appearance in the two seasons (75.85 and $76.26 \%$ reduction in disease incidence at 2017 and 2018, respectively) and in disease severity $(60.97$ and $63.04 \%$ reduction at 2017 and 2018, respectively). 
Table 1: Effect of two concentrations of three antioxidants on the linear growth of Alternaria solani in vitro.

\begin{tabular}{lccc}
\hline Treatments & Concentrations (mg /) & Linear growth $(\mathbf{m m})$ & Reduction (\%) \\
\hline \multirow{2}{*}{ Salicylic acid } & 15 & $27^{\mathrm{e}}$ & 70.00 \\
\cline { 2 - 4 } & 30 & $17^{\mathrm{g}}$ & 81.11 \\
\hline \multirow{2}{*}{ Ascorbic acid } & 15 & $30^{\mathrm{d}}$ & 66.66 \\
\cline { 2 - 4 } & 30 & $21^{\mathrm{f}}$ & 76.66 \\
\hline \multirow{2}{*}{ Boric acid } & 15 & $44^{\mathrm{b}}$ & 51.11 \\
\cline { 2 - 4 } & 30 & $36^{\mathrm{c}}$ & 60.00 \\
\hline Control & - & $90^{\mathrm{a}}$ & -
\end{tabular}

Values with the same letter are not significantly different at 5\% probability level by Duncan's Multiple Range Test.

Table 2: Effect of two concentrations of three antioxidants on early blight disease incidence on tomato plants under greenhouse condition during 2017 and 2018 growing seasons.

\begin{tabular}{lccccc}
\hline \multirow{2}{*}{ Treatments } & \multirow{2}{*}{$\begin{array}{c}\text { Concentrations } \\
(\mathbf{m g} / \mathbf{l})\end{array}$} & $\begin{array}{c}\text { 2017 season } \\
\text { incidence }\end{array}$ & $\begin{array}{c}\text { Reduction } \\
\mathbf{( \% )}\end{array}$ & $\begin{array}{c}\text { Disease } \\
\text { incidence }\end{array}$ & $\begin{array}{c}\text { Reduction } \\
\mathbf{( \% )}\end{array}$ \\
\cline { 2 - 6 } Salicylic acid & 15 & $1.05^{\mathrm{e}}$ & 50.70 & $0.95^{\mathrm{e}}$ & 52.02 \\
\cline { 2 - 6 } & 30 & $0.52^{\mathrm{g}}$ & 75.58 & $0.47^{\mathrm{g}}$ & 76.26 \\
\hline \multirow{2}{*}{ Ascorbic acid } & 15 & $1.32^{\mathrm{d}}$ & 38.02 & $1.27^{\mathrm{d}}$ & 35.85 \\
\hline \multirow{2}{*}{ Boric acid } & 30 & $0.75^{\mathrm{f}}$ & 64.78 & $0.72^{\mathrm{f}}$ & 63.63 \\
\hline Control $(A$. solani) & 15 & $1.60^{\mathrm{b}}$ & 24.88 & $1.57^{\mathrm{b}}$ & 20.70 \\
\hline Values with the same letter are not significantly different at $5 \%$ probability level by Duncan's Multiple Range Test.
\end{tabular}

Table 3: Effect of two concentrations of three antioxidants on early blight disease severity on tomato plants under greenhouse condition during 2017 and 2018 growing seasons.

\begin{tabular}{lccccc}
\hline \multirow{2}{*}{ Treatments } & $\begin{array}{c}\text { Concentrations } \\
(\mathbf{m g} / \mathbf{l})\end{array}$ & \multicolumn{2}{c}{ 2017 season } & \multicolumn{2}{c}{ 2018 season } \\
\cline { 2 - 5 } & 15 & $\begin{array}{c}\text { Disease } \\
\text { severity }\end{array}$ & Reduction (\%) & $\begin{array}{c}\text { Disease } \\
\text { severity }\end{array}$ & Reduction (\%) \\
\hline \multirow{2}{*}{ Salicylic acid } & 30 & $23.9^{\mathrm{e}}$ & 55.15 & $22.5^{\mathrm{e}}$ & 55.53 \\
\hline \multirow{2}{*}{ Ascorbic acid } & 15 & $20.8^{\mathrm{g}}$ & 60.97 & $18.7^{\mathrm{g}}$ & 63.04 \\
\hline \multirow{2}{*}{ Boric acid } & 30 & $28.5^{\mathrm{d}}$ & 46.52 & $26.7^{\mathrm{d}}$ & 47.23 \\
\hline Control (A. solani) & 15 & $22.2^{\mathrm{f}}$ & 58.34 & $20.7^{\mathrm{f}}$ & 59.09 \\
\hline Values & 30 & $36.9^{\mathrm{b}}$ & 30.76 & $35.5^{\mathrm{b}}$ & 29.84 \\
\hline
\end{tabular}

Values with the same letter are not significantly different at 5\% probability level by Duncan's Multiple Range Test.

While the lowest inhibitory effect on disease appearance was observed by boric acid $15 \mathrm{mg} / 1$ (24.88 and $20.70 \%$ reduction in disease incidence and in disease severity ( 30.76 and $29.84 \%$ reduction at 2017 and 2018 seasons).

Growth characters:

Data illustrated at Table (4) showed that, all treatments caused a significant increase in all growth characters, i.e. root length, plant height, leaf area, fresh and dry weight. The maximum increase in all growth characters were recorded at the second level of salicylic acid treatment increased by a bought $8.3,2.5,18.68,1.35$ and $0.12 \%$ over the control plants respectively, at the first season compared to control plants. The same trend was observed in the second season.
Water relations:

Data in Table (5) cleared that, TWC, free water, bound water and RWC were increased at the all levels of antioxidants under test as this sequences salicylic acid, ascorbic acid and boric acid. Meanwhile, the osmotic pressure and the transpiration rate were decreased at the same levels of antioxidants. The second level of salicylic acid recorded a highest increase in TWC, free water, bound water and RWC in tomato leaves. The increase rate over the control plants was a bought $7.02,0.49,6.53$ and $3.94 \%$, respectively, when compared with the control plants. Similar results were obtained in the second season. 
As shown in Table(6) during the two growing seasons of 2016 and 2017 all applied treatments of antioxidants led to significant increase of chlorophyll a, chlorophyll b, carotenoids, total carbohydrates, total sugars, protein and prolien in leaves of treated tomato plants. There was remarkable highest increase in chemical composition and photosynthetic pigments at the second level of salicylic acid followed by the second level of ascorbic acid.

Table 4: Effect of some antioxidants on growth characters of tomato plants grown under greenhouse and artificially infected with Alternaria solani at two growing seasons 2017 and 2018.

\begin{tabular}{|c|c|c|c|c|c|c|}
\hline Treatments & Characters & $\begin{array}{l}\text { Root } \\
\text { length } \\
(\mathrm{cm}) \\
\end{array}$ & $\begin{array}{c}\text { Plant } \\
\text { height } \\
(\mathrm{cm})\end{array}$ & $\begin{array}{c}\text { Leaf area } \\
\quad\left(\mathrm{cm}^{2}\right)\end{array}$ & $\begin{array}{c}\text { Fresh } \\
\text { weight } \\
\text { (g) }\end{array}$ & $\begin{array}{c}\text { Dry } \\
\text { weight } \\
\text { (g) } \\
\end{array}$ \\
\hline & $\mathrm{mg} / \mathrm{l}$ & & & Season 2017 & & \\
\hline Control & 0 & 26.3 & 58.9 & 147.40 & 31.76 & 2.74 \\
\hline Alternaria solani & 0 & 21.8 & 49.2 & 122.83 & 26.53 & 2.29 \\
\hline Salicylic acid & 15 & 32.8 & 63.3 & 166.25 & 34.14 & 2.94 \\
\hline Salicylic acid & 30 & 34.6 & 61.4 & 166.08 & 33.11 & 2.86 \\
\hline Ascorbic acid & 15 & 28.4 & 62.4 & 157.08 & 33.65 & 2.90 \\
\hline Ascorbic acid & 30 & 33.9 & 59.6 & 161.76 & 32.14 & 2.77 \\
\hline Boric acid & 15 & 29.1 & 57.7 & 150.16 & 31.12 & 2.68 \\
\hline Boric acid & 30 & 29.5 & 59.2 & 153.45 & 31.92 & 2.75 \\
\hline \multirow{2}{*}{ LSD at $5 \%$} & & 0.0009 & 1.058 & 0.129 & 0.039 & 0.032 \\
\hline & & & & Season 2018 & & \\
\hline Control & 0 & 27.0 & 60.5 & 146.43 & 32.95 & 2.84 \\
\hline Alternaria solani & 0 & 22.3 & 50.3 & 121.89 & 27.47 & 2.37 \\
\hline Salcylic acid & 15 & 33.1 & 63.9 & 160.34 & 36.69 & 3.16 \\
\hline Salcylic acid & 30 & 35.3 & 62.6 & 159.40 & 36.37 & 3.14 \\
\hline Ascorbic acid & 15 & 29.1 & 63.8 & 155.31 & 35.06 & 3.02 \\
\hline Ascorbic acid & 30 & 34.6 & 60.8 & 155.09 & 35.39 & 3.05 \\
\hline Boric acid & 15 & 29.2 & 57.9 & 144.83 & 33.22 & 2.86 \\
\hline Boric acid & 30 & 30.2 & 60.6 & 150.06 & 33.98 & 2.93 \\
\hline LSD at $5 \%$ & & 0.0006 & 1.090 & 0.127 & 0.046 & 0.038 \\
\hline
\end{tabular}

Table 5: Effect of some antioxidants on water relations of tomato plants grown under artificial infection with Alternaria solani at two growing seasons 2017 and 2018.

\begin{tabular}{|c|c|c|c|c|c|c|c|}
\hline Treatments & acters & $\begin{array}{c}\text { TWC } \\
(\%)\end{array}$ & $\begin{array}{c}\text { Free } \\
\text { water } \\
(\%)\end{array}$ & $\begin{array}{c}\text { Bound } \\
\text { water } \\
(\%)\end{array}$ & $\begin{array}{c}\text { RWC } \\
(\%)\end{array}$ & $\begin{array}{l}\text { O.P. } \\
\text { C.S. } \\
\text { (bar) }\end{array}$ & $\begin{array}{l}\text { Trans rate } \\
\text { (mg/g fw.h) }\end{array}$ \\
\hline & $\mathrm{mg} / \mathrm{l}$ & \multicolumn{6}{|c|}{ Season 2017} \\
\hline Control & 0 & 81.09 & 11.65 & 69.44 & 75.08 & 2.36 & 0.027 \\
\hline Alternaria solani & 0 & 78.47 & 9.73 & 68.74 & 72.66 & 2.39 & 0.028 \\
\hline Salicylic acid & 15 & 86.14 & 12.52 & 73.62 & 77.26 & 2.28 & 0.025 \\
\hline Salicylic acid & 30 & 88.11 & 12.14 & 75.97 & 79.02 & 2.23 & 0.023 \\
\hline Ascorbic acid & 15 & 84.89 & 12.34 & 72.55 & 77.88 & 2.24 & 0.025 \\
\hline Ascorbic acid & 30 & 87.59 & 11.79 & 75.80 & 78.56 & 2.23 & 0.023 \\
\hline Boric acid & 15 & 78.91 & 11.41 & 67.50 & 74.80 & 2.29 & 0.027 \\
\hline Boric acid & 30 & 79.73 & 11.71 & 68.02 & 75.57 & 2.29 & 0.027 \\
\hline \multirow[t]{2}{*}{ LSD at $5 \%$} & & 0.0009 & 0.437 & 1.629 & 0.495 & 1.994 & 0.0005 \\
\hline & & \multicolumn{6}{|c|}{ Season 2018} \\
\hline Control & 0 & 81.02 & 11.62 & 69.40 & 74.79 & 2.37 & 0.026 \\
\hline Alternaria solani & 0 & 76.93 & 9.56 & 67.37 & 71.22 & 2.41 & 0.022 \\
\hline Salcylic acid & 15 & 85.25 & 12.45 & 72.80 & 76.40 & 2.29 & 0.028 \\
\hline Salcylic acid & 30 & 87.22 & 12.08 & 75.14 & 78.16 & 2.24 & 0.027 \\
\hline Ascorbic acid & 15 & 83.97 & 12.24 & 71.73 & 77.00 & 2.24 & 0.027 \\
\hline Ascorbic acid & 30 & 85.86 & 11.69 & 74.27 & 76.97 & 2.24 & 0.026 \\
\hline Boric acid & 15 & 78.07 & 11.39 & 66.68 & 73.89 & 2.30 & 0.025 \\
\hline Boric acid & 30 & 78.86 & 11.66 & 67.20 & 74.66 & 2.30 & 0.026 \\
\hline \multicolumn{2}{|c|}{ LSD at $5 \%$} & 0.0006 & 0.419 & 1.491 & 0.479 & 1.982 & 0.0006 \\
\hline
\end{tabular}


Table 6: Effect of some antioxidants on chemicals constituents of leaves of tomato plants grown under artificial infection with Alternaria solani at two growing seasons 2017 and 2018.

\begin{tabular}{|c|c|c|c|c|c|c|c|c|}
\hline Treatments & cters & $\begin{array}{c}\text { Chl. A. } \\
\text { (mg/g dwt) }\end{array}$ & $\begin{array}{c}\text { Chl. B. } \\
\text { (mg/g } \\
\text { dwt) }\end{array}$ & $\begin{array}{c}\text { Carote- } \\
\text { noides } \\
\text { (mg /g dwt) }\end{array}$ & $\begin{array}{c}\text { Total } \\
\text { Carbohy- } \\
\text { drates } \\
\text { (mg /g dwt) }\end{array}$ & $\begin{array}{c}\text { Total } \\
\text { sugars } \\
(\mathrm{mg} / \mathrm{g} \\
\mathrm{dwt})\end{array}$ & $\begin{array}{c}\text { Protein } \\
(\%)\end{array}$ & $\begin{array}{c}\text { Proline } \\
(\mu \mathrm{g} / \\
/ \mathrm{g} \text { dwt })\end{array}$ \\
\hline & $\mathrm{mg} / \mathrm{l}$ & \multicolumn{7}{|c|}{ Season 2017} \\
\hline Control & 0 & 3.18 & 1.14 & 1.29 & 0.824 & 0.015 & 24.27 & 238.31 \\
\hline Alternaria solani & 0 & 3.08 & 1.02 & 1.21 & 0.815 & 0.012 & 23.81 & 261.04 \\
\hline Salicylic acid & 15 & 3.27 & 1.23 & 1.32 & 0.841 & 0.017 & 24.97 & 282.41 \\
\hline Salicylic acid & 30 & 3.35 & 1.33 & 1.38 & 0.863 & 0.017 & 25.72 & 300.59 \\
\hline Ascorbic acid & 15 & 3.30 & 1.25 & 1.34 & 0.849 & 0.017 & 24.92 & 271.46 \\
\hline Ascorbic acid & 30 & 3.33 & 1.26 & 1.35 & 0.855 & 0.017 & 25.46 & 292.31 \\
\hline Boric acid & 15 & 3.17 & 1.14 & 1.27 & 0.828 & 0.015 & 24.44 & 264.66 \\
\hline Boric acid & 30 & 3.20 & 1.15 & 1.28 & 0.833 & 0.016 & 24.39 & 266.24 \\
\hline \multirow[t]{2}{*}{ LSD at $5 \%$} & & 0.088 & 0.116 & 0.057 & 0.008 & 0.0007 & 0.289 & 3.474 \\
\hline & & \multicolumn{7}{|c|}{ Season 2018} \\
\hline Control & 0 & 3.17 & 1.14 & 1.30 & 0.821 & 0.015 & 24.31 & 241.73 \\
\hline Alternaria solani & 0 & 3.02 & 1.00 & 1.18 & 0.799 & 0.013 & 23.79 & 250.85 \\
\hline Salcylic acid & 15 & 3.24 & 1.22 & 1.31 & 0.832 & 0.017 & 24.93 & 288.92 \\
\hline Salcylic acid & 30 & 3.31 & 1.32 & 1.36 & 0.854 & 0.017 & 25.67 & 297.01 \\
\hline Ascorbic acid & 15 & 3.26 & 1.24 & 1.32 & 0.839 & 0.017 & 24.88 & 281.01 \\
\hline Ascorbic acid & 30 & 3.27 & 1.23 & 1.34 & 0.838 & 0.017 & 25.56 & 283.30 \\
\hline Boric acid & 15 & 3.13 & 1.13 & 1.25 & 0.818 & 0.016 & 24.38 & 280.94 \\
\hline Boric acid & 30 & 3.16 & 1.14 & 1.26 & 0.823 & 0.016 & 24.35 & 275.82 \\
\hline LSD at $5 \%$ & & 0.079 & 0.121 & 0.060 & 0.009 & 0.0004 & 0.267 & 2.093 \\
\hline
\end{tabular}

\section{DISCUSSION}

Early blight disease caused by $A$. solani is one of most serious foliar diseases causing large yield losses in tomato plants especially in plastic houses (Jagadeesh and Jagadeesh, 2009). Fungicides could successfully control plant diseases; however, they have many hazardous effects on animal environment and human.

Plant resistance inducers are among the most important alternative methods for controlling plant diseases which are safe and rapidly biodegradable (Ragab et al., 2009). Application of ascorbic acid reduced significantly early blight disease incidence of

potato

(El-Gamal et al., 2007). Also, spray application of ascorbic acid to cucumber and pepper plants had a good effect on reducing the powdery and downy mildew disease severity (Abd El-Kader et al., 2012).

Salicylic acid plays an important role in induction resistance of plants to pathogens. According to Vallad and Goodman (2004) salicylic acid can induce accumulation of pathogenesisrelated proteins (PRP) and lead to reduced incidence of several diseases on many crops. Application of salicylic acid and ascorbic acid elicit production of tomatin (phytoalexin) in leaves and stems of tomato plants which is toxic to $A$. solani (Awadella, Omyma 2008). The results obtained by Ismail et al. (1988) showed that, salicylic acid had an inhibitory effect on germ tube length and lycopersici and Aspergillus fumigatus.

Exogenous application of salicylic acid delayed the development of Botrytis cinerea on tobacco leaves (Murphy et al., 2000).

The reduction of early blight disease on tomato plants which were treated with the antioxidants (salicylic acid, ascorbic acid and boric acid), improved growth characters, water relations, photosynthetic pigments and chemical constituents. Mady (2009) found that, different applied treatments (salicylic acid) significantly increased all studied growth parameters as number of branches and leaves per plant, leaf area per plant and leaves dry weight as well.

Sanaa et al. (2006) and Mady (2009) reported that, applied of salicylic acid or vitamin E obviously increased photosynthetic pigments, total carbohydrates and crude protein concentrations in leaves of treated plants as compared with those of untreated ones on bean and tomato plants. Application of salicylic acid to plants has shown a variety of biological responses.

The resistance of the disease depends on the chemical activity of the plant cell and the activity of the formation of particular protein or a particular enzyme. It's worth mentioning that all the metabolic activity in the plant depends on the good water balance in the cell which due to cell bloating, opening and closing of stomata and the hardness of the cell wall. 
Enzyme activities such as amylase and nitrate reductase were increased by salicylic acid application (Sharma et al., 1986 and Chen et al., 1993). On the other hand, SA showed synergetic effect with auxin and gibberellins (Datta and Nanda, 1985 and Sanaa et al., 2006). Moreover, in a number of species SA promoted flowering in combination with other plant growth regulators such as kinetin, indole acetic acid and gibberellins (Singh, 1984 and Shehata et al., 2000). Application of SA induced changeable in endogenous phytohormones of tomato and other plants (Raskin, 1992 and Waffaa et al., 1996).

In conclusion, the obtained results showed the antifungal effect of antioxidants and their value in controlling early blight disease and improved growth characters of treated tomato plants. So antioxidants could be recommended to control early blight disease and reduces the hazard of fungicides.

\section{REFERENCES}

Abd El-Kader, M.M.; El-Mougy, Nehal S.; Aly, M.D.E. and Lashin, S.M. (2012). Integration of biological and fungicidal alternatives for controlling foliar diseases of vegetables under greenhouse conditions. Int. J. of Agric. and Foresty, 2 (2): 38 - 48.

Abd El-Sayed, M.H.F. (2006). Pathological, physiological and molecular variations among isolates of Alternaria solani the causal of tomato early blight disease. Ph.D. Thesis, Fac. of Agric., Cairo Univ., p. 181.

A.O.A.C. (1995). Association of Official Agriculture Chemists. Official Methods of Analysis $12^{\text {th }}$ Ed. Washington, D.C.

Awadalla, Omyma A. (2008). Induction of systemic acquired resistance in tomato plants against early blight disease. Egypt. J. of Experiment. Biol., 4: 53 - 59 .

Barrs, H. D. and Weatherley, P. E. (1962). Arc examination of the relative turgidity technique for estimating water deficits in leaves. Aust. J. BioI. Sci., 15: 413 - 428.

Bates, L. S.; Waldem, R. P. and Teare, 1. D. (1973). Rapid determination of free proline under water stress studies. Plant and Soil, 39: 205 - 207.

Chaturvedi, R. and Shah, J. (2007). Salicylic acid in plant disease resistance. Salicylic acid: A Plant Hormone. Hayat, S and Ahmed A., eds. Springer, Dordrecht, The Netherlands. pp. 335 -370 .

Chen, Z.; Ricigllano, J. W. and Klessig, D. F. (1993). Purification and characterization of a soluble salicylic acid binding protein from tobacco. Proc. Natl. Acad. Sci. USA, 90: 9533 -9537 .
Cohen, Y.; Cisi, U. and Mosinger, E. (1991). Systemic resistance of potato plants against Phytophthora infestans induced by unsaturated fatty acids. Physiol., Molecular, Plant Pathol., 38: $255-263$.

Datta, K.S. and Nada, K.K.(1985). Effect of some phenolic compounds and gibberellic acid on growth and development of cheena millet (Panicum millasceum L.) Indian Journal of Plant Physiology, 28: 298-302.

El-Gamal, G.N.; Abd El-Kareem, F.; Fotouh, Y.O. and El-Mougy, S.N. (2007). Induction of systemic resistance in potato plants against late and early blight diseases using chemical inducers under greenhouse and field conditions. Res. J. of Agric. Biol. Sci., 3 (2): 73 - 81.

Ellis, M.B. (1971). Dematiaceous Hyphomycetes. Kew, Surrey, common Wealth Mycological Institute, 608pp.

Esmail Zadeh, M.; Soleimani, M.J. and Rouhani, H. (2008). Exogenous applications of salicylic acid for inducing systemic acquired resistance against tomato stem canker disease. J. Biol. Sci., 8: 1039 - 1044.

Fladung, M. and Ritter E. (1991). Plant Leaf Area Measurements by Personal Computers. J. of Agron. and Crop Sci., 111 (1): 19 - 27.

Galal, A.A. and Abdou, E.L. (1996). Antioxidants for the control of fusarial diseases in cowpea. Egypt. J. of Phytopathol., 24: 1 - 12.

Gomez, K. A. and A. A. Gomez (1984): Statistical procedures for agricultural research. $2^{\text {nd }}$ ed. Jahn Wiley Sons, New York, U.S.A. pp. 680.

Gosev, N. A. (1960): Some methods in studying plant water relation. Leningrad Acad. of Sci. U.S.S.R.

Hossain, M.H.; Bhowal, S.K.; Haque, A.K.M. and Khan, A.S. (2011). Management of common scab (Streptomyces scablies) of potato. Res. J. of Agric. and Environ. Management. 4 (11): $497-495$.

Ismail, Amal A. (2015). Management of potato early blight. Menoufiya J. of Agric. Res., 40, 4 (7): $891-899$.

Ismail, I.M.K.; Salama, A.M.; Ali, M.I.A. and Ouf, S.A. (1988). Effect of some phenolic compounds on spore germination and germtube length of Aspergillus fumigatus and Fusarium oxysporum f.sp. lycopersici. Egypt. J. of Microbiol., 23: $29-41$.

Jagadeesh, K.S. and Jagadeesh, D.R. (2009). Biological control of early blight of tomato caused by Alternaria solani as influenced by different delivery methods of Pseudomonas gladioli B25. Acta Hort., 808: 327 - 332. 
Jayasinghe, C.K. and Wijesundera, R.L. (1995). In vitro evaluation of fungicides against clove isolate of Cylindrocladium quinqueseptatum in Srilanka. Inter. J. of Pest Management, 41 (4): $219-223$.

Kreeb, K. H. (1990): Methoden Zur Pflanzenokologie und Bioindikation Gustav Fisher, Jena, p. 327.

Mady, M.A. (2009). Effect of foliar application with salicylic acid and vitamin $\mathrm{E}$ on growth and productivity of tomato (Lycopersicon esculentum, Mill.). Plant J. Agric. Sci., Mansoura Univ., 34 (6): 6735 - 6746.

Mate, G.D.; Deshmukh, V.V. and Mayer, D. (2005). Efficacy of plant products and fungicides on tomato early blight caused by Alternaria solani. Res. Crops, 6: 349 - 351.

Murphy, A.M.; Holcombe, L.J. and Carr, J.P. (2000). Characteristics of salicylic acid-induced delay in disease caused by a necrotrophic fungal pathogen in tobacco. Physiol. And Molecular Plant Pathol., 57: 47 - 45.

Ragab, M.M.; Saber, M.M.; El-Morsy, S.A. and Abd El-Aziz, A.R.M. (2009). Induction of systemic resistance against root-rot of basil using some chemical inducers. Egypt. J. of Phytopathol., 37 (1): 59 - 70.

Raskin, I. (1992). Role of salicylic acid in plants. Annual Rev. Plant Phsyiol., Plant Mol. Biol., 43: $439-463$.

Saad, A.S.A.; Kadous, E.A.; Tayeb, E.H.; Massoud, M.A.; Ahmed, Soad M. and Abou El-Ela, A.S.A. (2014). The inhibitory effect of some antioxidants and fungicides on the growth of Alternaria solani and Fusarium solani in vitro. Middle East J. of Agric. Res., 3 (2): 123 - 134.

Safari, S.; Soleimani, M.J.; Mohajer, A. and Fazlikhani, L. (2013). Possible structureactivity profile of salicylate derivatives: their relationship on induction of systemic acquired resistance. J. of Agric. Technol., 9 (5): 1215 1225.
Sanaa, A.M.; Mostafa, M.A. and Shehata, S.A.M. (2006). Physiological studies on the effect of kinetin and salicylic acid on growth and yield of wheat plant. Annals Agric. Sci., Ain Shams Univ., Cairo, 51 (1): 41 - 55.

Sanaa, Z.A.M.; Ibrahim, S.I. and Sharaf Eldeen, H.A.M. (2001). The effect of naphthaline acetic acid (NAA), salicylic acid (SA) and their combination on growth, fruit setting yield and some correlated components in dry bean (Phaseolus vulgaris L.). Annals Agric. Sci., Ain Shams Univ., Cairo, 46 (2): 451 - 463.

Sharma, S.; Sharma, S.S. and Rau, V.K. (1986). Reversal by phenolic compounds of abscisic acid induced inhibition of in vitro activity of amylase from seeds of Tricium aestivum L. New-Phytologist, 103 (2): 293 - 297.

Shehata, S.A.M.; Saeed, M.A. and Abou El-Nour, M.S. (2000). Physiological response of cotton plant to the foliar spray with salicylic acid. Annals Agric. Sci., Ain Shams Univ., Cairo, 45 (1): $1-18$.

Singh, S.P. (1984). Auxin synergists in regeneration of roots in cutting of Chrysanthemum morifoilicum Romat. cv. Flirt under intermittent, mist National Academy of Sciences. Indian, Science Letters, 4 (4): 149 151.

Vallad, G.E. and Goodman, R.M. (2004). Systemic acquired resistance and induced systemic resistance in conventional agriculture. Crop Sci., 44: 1920 - 1934.

Waffaa, M.; Abdel-Ghafar, N.Y. and Shehata, S.A.M. (1996). Application of salicylic acid and aspirin for induction of resistance to tomato plants against bacterial wilt and its effect on endogenous hormones. Annals Agric. Sci., Ain Shams Univ., Cairo, 41 (2): 1007 - 1020. 


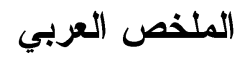

\section{تقييم بعض مضادات الأكسدة ضد مرض اللفحة المبكرة في الطماطم}

\author{
محمد زكى الثناوى، أحمد محمد عبد العال

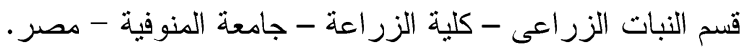

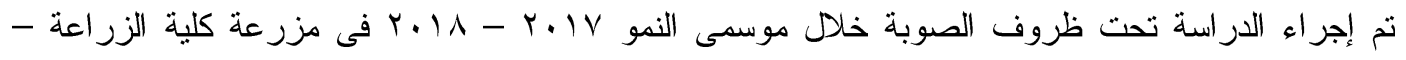

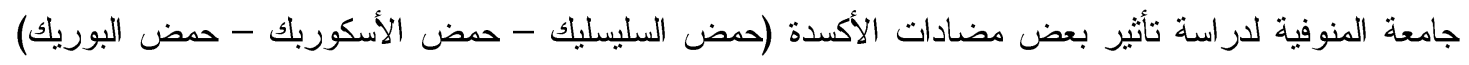

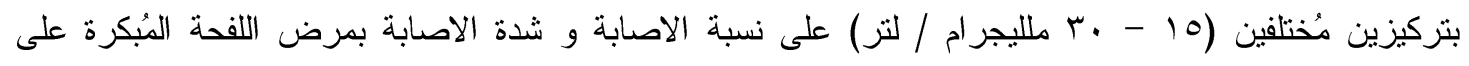

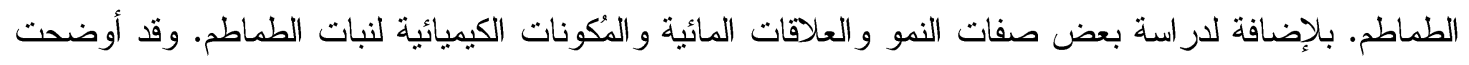

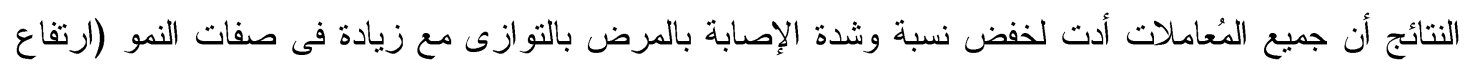

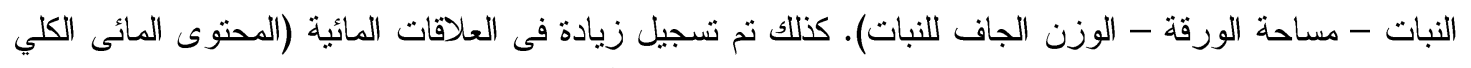

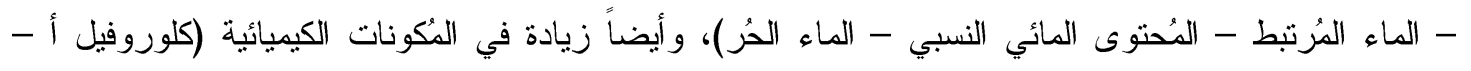

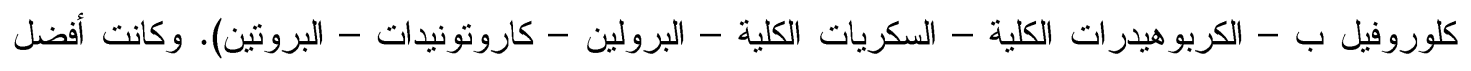

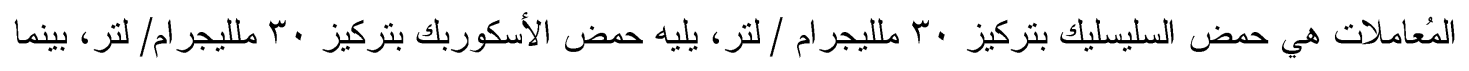

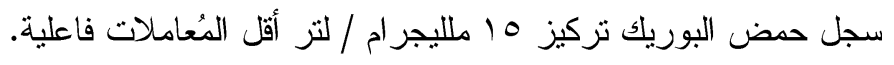

